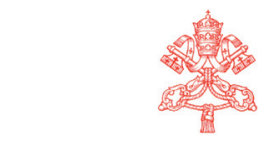

CONGREGAZIONE

PER L'EDUCAZIONE CATTOLICA

IL CARDINALE PREFETTO
„Analecta Cracoviensia” 46 (2014), s. 309

DOI: http://dx.doi.org/10.15633/acr.969

kard. Zenon Grocholewski

Prefekt Kongregacji Edukacji Katolickiej

\title{
List do Redaktora Naczelnego „Analecta Cracoviensia"
}

Watykan, 4 października 2014

Przewielebny Księże Profesorze,

serdecznie dziękuję za najnowszy numer czasopisma naukowego „Analecta Cracoviensia", w którym umieszczono prezentacje Księgi Jubileuszowej Quod iustum est et requum oraz książki Uniwersytety wobec wspótczesnych wyzwań.

Jestem wdzięczny redakcji czasopisma oraz autorowi recenzji księdzu profesorowi Janowi Maciejowi Dyduchowi za podjęty trud przedstawienia obydwu publikacji na łamach czasopisma Uniwersytetu Papieskiego Jana Pawła II w Krakowie.

Życząc Księdzu Profesorowi oraz całej Redakcji rocznika „Analecta Cracoviensia” obfitości Bożych łask w codziennym trudzie ubogacania naukowego środowiska krakowskiego, przesyłam szczere pozdrowienia i z serca błogosławię,

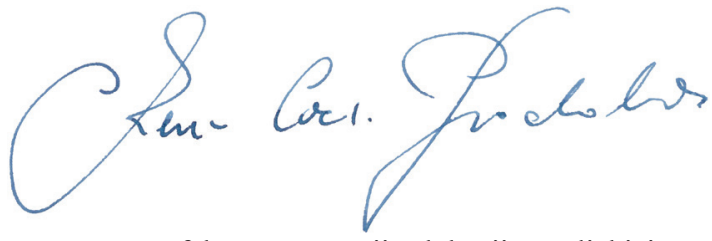

Prefekt Kongregacji Edukacji Katolickiej

Przewielebny

ks. prof. dr hab. Józef Makselon

Redaktor Naczelny „Analecta Cracoviensia”

Kraków 
